\title{
Collecting, drying, and preserving feces for chemical and microhistological analysis
}

\author{
RAY T. HINNANT AND M.M. KOTHMANN
}

\begin{abstract}
Chemical and botanical analyses of feces provide information on diet quality and composition that is not easily collected directly from a grazing animal. However, fecal excreta is readily available in the pastures the animals are grazing. This study was conducted to determine the feasibility of collecting fecal samples from the pasture for chemical (nitrogen) and botanical analysis. Two experiments were conducted to determine the effects of method of drying (oven-dried vs. freeze-dried) and duration of fecal pat exposure on chemical and microhistological analyses. Concentration of nitrogen was not affected by method of drying or by duration of exposure in the field. Samples $<72$ hours during the winter and $<24$ hours during the summer may be used for nitrogen analysis. However, we recommend that samples be collected as soon as possible following defecation to reduce possible negative effects of precipitation, insect damage, and trampling. Method of drying had no significant $(P<0.05)$ effect on percentage of identifiable fragments or subsequent forage class determination. Bleach, as a blending medium reduced pigment masking of epidermal fragments resulting in an increase in the percentage of identifiable epidermal fragments. Duration of exposure did not affect identincation of most of the forage classes. The proportion of identifiable fragments, was lower during winter than summer.
\end{abstract}

Key Words: nitrogen, fecal nitrogen, diet quality, microhistological analysis, fecal analysis

The nitrogen content of feces has frequently been used to predict diet quality and nutrient intake of grazing ruminants. Fecal samples can also be analyzed to estimate botanical composition of the diet. Analysis of feces may yield much ecological information (Putman 1984). Use of fecal nitrogen to estimate nitrogen concentration of forage grazed by sheep may be more accurate than estimates obtained by analysis of cut herbage (Raymond 1948). Wofford et al. (1985) and Sinclair et al. (1982) also found a strong relationship between percentage of diet nitrogen and fecal nitrogen. Significant relationships exist between fecal nitrogen and the digestibility and intake of forage (Hutchinson 1958, Fels et al.

Authors are research associate and professor, Texas Agricultural Experiment Station, Department of Range Science, Texas A\&M Univ. College Station 77840.

Approved by the Director, Texas Agricultural Experiment Station as TA 21784.

Manuscript accepted 14 October 1987.
1959, Arnold and Dudzinski 1963, Renecker and Hudson 1985). The primary advantage of the fecal nitrogen technique is that there is no need to disturb, fistulate, or sacrifice the animals (Erasmus et al. 1978). The technique has further advantages if fecal samples could be collected from the pasture post defecation rather than as rectal samples.

Oven drying requires less time than freeze-drying, which may take 3-7 days. Freeze-drying substantially increases the cost of sample preparation for analyses and delays results. Harris (1970) defined oven-drying as $105^{\circ} \mathrm{C}$ until a constant weight and partial oven-drying as $60^{\circ} \mathrm{C}$ in a forced convection oven with about $12 \%$ moisture remaining. Freeze-drying is usually considered partial drying. Raymond and Harris (1954) found oven-drying unacceptable for accurate determination of fecal nitrogen and recommended analysis of fresh feces. Losses of nitrogen from -3 to $34 \%$ have been reported at oven temperatures of $65-100^{\circ} \mathrm{C}$ with varying drying times (Colovos et al. 1957, Bredon et al. 1961, Falvey and Woolley 1974). Partial-drying of feces at $60-65^{\circ} \mathrm{C}$ in a forceddraft oven resulted in nitrogen losses of 4-6\% (Gallup and Hobbs 1944) or no loss (Forbes et al. 1946).

Two methods commonly used to estimate diet composition are microscopic examination of esophageal fistula and fecal samples. The latter technique was described by Baumgartner and Martin (1939), Sparks and Malechek (1968), and more recently modified by Holechek and Valdez (1985). This technique uses unique identifiable characteristics of epidermal cells as the basis of plant species identification. Identifiable features include size and shape of epidermal hairs, cell shapes, and crystals in epidermal cells (Sparks and Malechek 1968).

The proportion of epidermal fragments that can be identified is affected by the method of sample preparation and season of collection (Holechek 1982). Use of bleach (Williams 1969) and sodium hydroxide solutions (Vavra and Holechek 1980) can improve identifiable characteristics fecal samples by removing pigment masking from the cells. However, Holechek (1982) found bleach and sodium hydroxide may damage some plant material.

The first objective of this study was to determine the changes in nitrogen concentration of feces with duration of exposure. Feces were dried by 2 methods, partial oven-drying and freeze-drying. 
The second objective was to determine the effects of the 2 drying methods, the addition of bleach to the blending medium, and the duration of exposure on microhistological identification of plant fragments.

\section{Methods}

Experiments were conducted to evaluate effects of method of drying on chemical and physical constituents of fecal samples collected from the Sonora Research Station, Sonora, Texas, during winter and from the Native Plant \& Animal Conservancy, College Station, Texas, during summer.

\section{Method of Drying}

The first experiment compared effects of freeze-drying and oven-drying on chemical and physical contents of fecal samples. These samples were collected from a herd of cows grazing in a short-duration grazing study. Two equal (300-g, fresh weight) sub-samples were taken from 5 fresh fecal pats for 5 days during January 1980. All samples were frozen with 2 hours following collection for preservation. One sub-sample was freeze-dried, and the other partially oven-dried at $60^{\circ} \mathrm{C}$ for 24 hours. Samples were ground through a Wiley mill fitted with a $1-\mathrm{mm}$ screen prior to analysis.

A second experiment was conducted to detect chemical and physical changes over time in fecal pats on the ground. Fresh sample fecal pats were identified and the cows were moved to a different pasture to prevent trampling damage. Ten pats were staked and initial samples collected immediately after defecation. Identified pats were subsequently sampled at $6,24,48$, and 72 hours after defecation at Sonora and at 6 and 24 hours at College Station. There were no fecal collections for the 48- and 72-hour periods during the summer because the pat was decimated by insect activity. The crust of the pat was avoided when possible. No measurable precipitation occurred during either collection period. Samples were stored, dried, and ground as in the previous experiment.

\section{Chemical Analysis}

Dry matter $\left(105^{\circ} \mathrm{C}\right.$ for 24 hours) and organic matter $\left(550^{\circ} \mathrm{C}\right.$ for 3 hours) were determined from sub-samples for each sample. Nitrogen was analyzed by the micro-Kjeldahl method (AOAC 1975). Nitrogen is reported on an oven-dry, ash-free basis.

\section{Microhistological Analysis}

Samples collected from experiments 1 and 2 were used to examine the effects of drying method, blending medium, and duration of exposure on microhistological fragment identification. Ground fecal samples from the method of drying and blending medium experiments were composited across 5 pats within drying method and days. Samples were composited across 10 staked pats within collection periods from the duration of exposure study. Half of the samples from each experiment were blended for $1 \mathrm{~min}$ with $95 \%$ ethanol and the slides prepared with Hertwigs and Hoyers solutions (Sparks and Malechek 1968). The other set of samples was blended for $1 \mathrm{~min}$ with sodium hypochlorite (household bleach) and then slides were prepared as above. Five slides were made from each sample and 10 fields per slide were read by personnel at the diet laboratory at Texas Tech University (Scott and Dahl 1980). Total fragments in each field were counted. Fragments were placed into 3 categories: identifiable epidermal fragments, non-identifiable epidermal fragments, and non-epidermal fragments (NE). These categories were chosen to determine the effects of method of drying, blending medium, and duration of exposure on the proportion of identifiable and non-identifiable fragments. Identifiable fragments in each field were counted and recorded according to plant category. Plant categories were: warm-season perennial grasses, cool-season perennial grasses, forbs, browse, and cacti. Nonidentifiable epidermal fragments were further categorized as: Lacked characteristics-The fragment was large enough and was not damaged, but there were not enough identifiable characteris- tics present to make a positive identifications; Pigment-Tissue was identified as epidermal but pigment masked the identifiable characteristics; Damaged-Epidermal fragments were too small or mutilated to be identified.

The proportion of NE fragments was calculated as NE fragments divided by total number of fragments. The proportion of identifiable fragments was calculated as identifiable fragments divided by total epidermal fragments. Proportion data were transformed prior to statistical analysis by an arc-sine, square root transformation developed for binomial proportion data (Snedecor and Cochran 1980). Data were analyzed statistically by general linear model (GLM) procedures (SAS 1982). Mean separation was performed using Duncan's (1955) multiple range test.

\section{Results and Discussion}

\section{Chemical Analysis \\ Method of Drying}

We observed no significant differences $(P<.05)$ in nitrogen content of oven-dried $(1.35 \% \mathrm{~N})$ or freeze-dried $(1.38 \% \mathrm{~N})$ feces. Oven-drying fecal samples reduced sample preparation time for chemical analysis. Lower temperatures $\left(<60^{\circ} \mathrm{C}\right)$ and an oven with a high air flow is recommended to prevent the detrimental effect of high temperatures combined with high moisture for long durations in the oven (Raymond and Harris 1954).

\section{Duration of Exposure}

Mean nitrogen content of feces collected fresh through 72 hours in winter $(1.2 \% \mathrm{~N})$ and fresh through 24 hours in summer $(1.8 \% \mathrm{~N})$ was not affected $(P<0.05)$ by duration of exposure. It is difficult to determine the age of a fecal pat in a pasture. Fecal pats tend to be extremely moist when forage is actively growing and dry when forage is dormant because of varying moisture content of forages. Observations of fecal pats in the pasture over a few days should allow a person to estimate the approximate age of the pat.

Because there was no effect of exposure time on fecal nitrogen content during winter or summer, age of pat should be of little consequence for fecal nitrogen monitoring within the sampling periods reported in our study. However, it is recommended that samples analyzed for chemical analysis be collected at defecation or as soon thereafter as possible to avoid possible effects of precipitation, trampling, insect loss or addition, and crusting.

\section{Microhistological Analysis}

\section{Method of drying}

Drying method had no effect on the percentage of NE fragments $(P<0.05)$ (Table 1). Approximately $46 \%$ of the fragments in all samples were not epidermal, or were unrecognizable as epidermal fragments. Method of drying had no effect on percentage of identifiable or non-identifiable epidermal fragments, or any of the diet categories when averaged across blending mediums. Samples which were oven-dried had approximately twice the non-identifiable epidermal fragments in the pigment category as compared to freeze-drying. Oven-drying of frozen samples appeared to "bleed" the pigment during defrosting onto other unidentifiable characteristic, especially those fragments which lacked adequate characteristics and damaged epidermal fragments (Table 1). Non-identifiable cells placed into the damaged category in the freeze-dried samples were increased $(P<0.05)$ due to a reduction in pigment masking rather than the drying method. Freezing of samples, weathering of dormant vegetation, and mastication prior to consumption were suspected of causing the high proportion of damaged epidermal cells with both drying methods.

\section{Blending Medium}

Use of bleach in sample preparation increased the percentage of identifiable and NE fragments and decreased the percentage of non-identifiable fragments $(P<0.05)$ (Table 1$)$. Bleach treatment allowed an approximate $15 \%$ increase in the recognition of some identifiable epidermal and NE fragments masked by pigmentation 
Table 1. Mean percentages of non-epidermal and identinable and nonidentifiable epidermal fragments in two drying methods and two blending mediums.

\begin{tabular}{|c|c|c|c|c|}
\hline \multirow[b]{2}{*}{ Category } & \multicolumn{2}{|c|}{ Drying method } & \multicolumn{2}{|c|}{ Blending medium } \\
\hline & Oven-dried & Freeze-dried & Bleach & Ethanol \\
\hline \multirow[t]{2}{*}{$\begin{array}{l}\text { NE } \\
\text { Identifiable } \\
\text { Non-identifiable }\end{array}$} & $\begin{array}{l}45.5 \\
12.2 \\
42.3\end{array}$ & $\begin{array}{l}46.3 \\
12.1 \\
41.6\end{array}$ & $\begin{array}{l}51.8^{x} \\
14.1^{x} \\
34.1^{x}\end{array}$ & $\begin{array}{l}40.0^{y} \\
10.2^{y} \\
49.8^{y}\end{array}$ \\
\hline & \multicolumn{4}{|c|}{ Identifiable epidermal fragments } \\
\hline $\begin{array}{l}\text { Warm season } \\
\text { grass } \\
\text { Cool season } \\
\text { grass } \\
\text { Browse } \\
\text { Forbs } \\
\text { Cactus }\end{array}$ & $\begin{array}{r}18.7 \\
9.7 \\
1.8 \\
6.9\end{array}$ & \begin{tabular}{r|r|}
58.3 \\
\\
20.2 \\
11.4 \\
2.8 \\
7.3
\end{tabular} & $\begin{array}{r}60.7 \\
\\
20.1 \\
8.3 \\
2.7 \\
8.2\end{array}$ & $\begin{array}{r}60.5 \\
\\
18.8 \\
12.8 \\
1.9 \\
6.0\end{array}$ \\
\hline Cactus & \multicolumn{4}{|c|}{ Non-identifiable epidermal fragments } \\
\hline $\begin{array}{l}\text { Too much } \\
\text { pigment } \\
\text { Lacked adequate } \\
\text { characteristics } \\
\text { Damaged }\end{array}$ & $\begin{array}{r}30.4^{n} \\
4.2^{a} \\
65.4^{n}\end{array}$ & $\begin{array}{l}17.4^{\mathrm{b}} \\
11.0^{\mathrm{b}} \\
71.6^{\mathrm{b}}\end{array}$ & $\begin{array}{r}11.1^{x} \\
6.5 \\
82.4^{x}\end{array}$ & $\begin{array}{c}8.6 \\
54.6^{y}\end{array}$ \\
\hline
\end{tabular}

$a, b, x, y$ Means in the same row within drying method and blending medium experiments, not followed by the same letter are significantly different $(P<.05)$.

which otherwise would have been included in one of the nonidentifiable epidermal fragment categories. These results appear to support the findings of Williams (1969) and Vavra and Holechek (1980). They found bleach and sodium hydroxide reduced the number of unidentifiables due to pigment and allowed more fragments to be identified. Holechek (1982) also found an increase in identifiable fragments of samples treated with bleach.

There was no difference in the calculated percentage of diet categories using either blending medium (Table 1). The percentage of non-identifiable fragments due to too much pigment was reduced $(P<.05)$. Bleach reduced fragment masking resulting in an increase in identifiable fragments and an increase in the damaged category $(P<.05)$. Holechek (1982) reported bleach damaged epidermal cells. The increased proportion of damaged epidermal cells when bleach was used resulted from a shift of fragments from the category of too much pigment into the damaged category.

\section{Duration of Exposure}

Duration of exposure significantly $(p<.05)$ affected the percentages of NE and non-identifiable epidermal fragments at both locations (Sonora and College Station) and identifiable epidermal fragments at College Station (Table 2). However, there was no discernable trend for any of the plant categories with increased exposure. Significant difference for browse at Sonora and forbs at College Station probably resulted from sampling variation within the fecal pat. Percentages of warm-season grass, cool-season grass, and browse were not affected by the duration of exposure through 24 hours at College Station and warm-season grass, cool-season grass, forbs, and cacti through 72 hours at Sonora.

The season in which samples were collected appeared to have the greatest effect on percentage NE, identifiable, and non-identifiable characteristics (Table 3). Samples collected in winter at Sonora had a higher percentage of NE fragments in the feces. Weathering of winter forage was believed to have caused a reduction in the proportion of epidermal cells. The proportion of identifiable fragments was approximately 10 times greater during the summer collection period compared to the dormant, weathered forage eaten during winter. Fragments which lacked adequate characteristics were higher $(p<0.05)$ for summer samples from College Station; however, the percentage of non-identifiable epidermal cells which were categorized as damaged was significantly greater from
Table 2. Percentages of forage claseses and percentages of non-epidermal and identifiable and non-identifiable epidermal fragments for varying durations of exposure (hours) at two locations.

\begin{tabular}{lccccc}
\hline \hline & \multicolumn{5}{c}{ Duration of exposure } \\
\cline { 2 - 6 } Sonora & 0 & 6 & 24 & 48 & 72 \\
\hline Warm season grass & 70.2 & 75.7 & 81.7 & 69.8 & 55.3 \\
Cool season grass & 9.9 & 6.6 & 10.4 & 15.8 & 7.8 \\
Browse & $9.3^{\mathrm{ab}}$ & $14.4^{\mathrm{ab}}$ & $5.4^{\mathrm{a}}$ & $3.7^{\mathrm{b}}$ & $20.9^{\mathrm{b}}$ \\
Forbs & 2.9 & 2.0 & 2.5 & 5.7 & 14.6 \\
Cactus & 7.7 & 1.4 & 0 & 5.0 & $1.3^{\mathrm{y}}$ \\
NE & $39.7^{\mathrm{b}}$ & $51.0^{\mathrm{a}}$ & $38.0^{\mathrm{bc}}$ & $33.4^{\mathrm{c}}$ & $41.2^{\mathrm{b}}$ \\
Identifiable & 2.3 & $2.3^{\mathrm{b}}$ & 1.9 & 1.4 & $2.4^{\mathrm{b}}$ \\
Non-identifiable & $58.0^{\mathrm{b}}$ & $46.2^{\mathrm{c}}$ & $60.0^{\mathrm{b}}$ & $65.2^{\mathrm{a}}$ & $56.4^{\mathrm{b}}$
\end{tabular}

\begin{tabular}{lrrr} 
& \multicolumn{3}{c}{ Duration of exposure } \\
\cline { 2 - 4 } College Station & 0 & 6 & \multicolumn{1}{c}{24} \\
\hline Warm season grass & 2.0 & 3.2 & 8.3 \\
Cool season grass & 0 & 0 & 0 \\
Browse & 73.0 & 65.3 & 70.7 \\
Forbs & $24.9^{x y}$ & $31.6^{x}$ & $21.0^{y}$ \\
NE & $33.5^{y}$ & $34.2^{y}$ & $41.1^{x}$ \\
Identifiable & $22.6^{x}$ & $24.8^{x}$ & $14.6^{y}$ \\
Non-identifiable & 43.9 & 41.0 & 44.3
\end{tabular}

$a, b, x, y$ Means in the same row not followed by the same letter are significantly different $(P<.05)$.

winter samples $(p<0.05)$ than samples collected in the summer. It is possible that samples were damaged by freezing prior to analysis, but the large difference due to season points to weathering as the major cause. Weathering breaks down cell structure and identifiable characteristics. Holechek (1982) also reported higher ratios of identifiable fragments in samples collected in summer compared to other seasons except with horse diets. He reported $80-90 \%$ unidentifiable fragments from winter diets of deer and fall prepared diets compared to $40 \%$ unidentifiable fragments from summer diets of cows. The technician reading the samples could not ascertain the excact causes of the damage to the cells.

Table 3. Effects of season of collection on the mean percentages of identifable and non-identifiable epidermal fragments and non-epidermal (NE) fragments.

\begin{tabular}{lcc}
\hline & \multicolumn{2}{c}{ Season } \\
\cline { 2 - 3 } & Summer & Winter \\
\hline NE & $36.3^{\mathrm{a}}$ & $40.7^{\mathrm{b}}$ \\
Identifiable & $20.6^{\mathrm{a}}$ & $2.1^{\mathrm{b}}$ \\
Non-identifiable & $43.1^{\mathrm{a}}$ & $57.2^{\mathrm{b}}$ \\
& Non-identifiable epidermal fragments \\
\cline { 2 - 3 } Too much pigment & $24.7^{\mathrm{a}}$ & $19.4^{\mathrm{a}}$ \\
Lack adequate characteristics & $18.6^{\mathrm{a}}$ & $1.4^{\mathrm{b}}$ \\
Damaged & $56.7^{\mathrm{a}}$ & $79.2^{\mathrm{b}}$ \\
\hline
\end{tabular}

a, $\mathrm{b}$ Means in the same row not followed by the same letter are different $(P<.05)$.

\section{Conclusions}

Fecal samples can be oven-dried $\left(60^{\circ}\right)$ to provide rapid analysis and yield accurate results for concentration of nitrogen and microhistological botanical composition. Oven drying reduced the sample preparation time compared to freeze drying. Fecal samples should be collected as soon as possible following defecation. However, the nitrogen concentration and the percentage of identifiable characteristics in most major plant categories were not affected by exposure through 72 hours in winter and 24 hours in the summer. Bleach in the blending medium reduced the effect of pigment 
masking and increased the proportion of identifiable epidermal cells. The percentage identifiable fragments in feces was significantly reduced when cattle were grazing dormant and weathered forage during winter compared to samples collected during the summer.

\section{Literature Cited}

AOAC. 1975. Official methods analysis. (11th Ed.) Association of Official Agricultural Chemists, Washington, DC.

Amold, G.W., and M.L. Dudzinaki. 1963. The use of fecal nitrogen as an index for estimating the consumption of herbage by grazing animals. J. Agr. Sci. 61:33-43.

Baumgartner, L.L., and A.C. Martin. 1939. Plant histology as an aid in squirrel food-habitat studies. J. Wildl. Manage. 3:266-268.

Bredon, R.M., C.D. Juko, and B. Marhall. 1961. The nutrition of Zebu cattle. Part III. Digestibility techniques: investigation of the effects of combination of dry faeces, length of digestibility trials and number of animals required. J. Agr. Sci. 56:99-103.

Colovos, N.F., H.A. Keener, and H.A. Davis. 1957. Errors in drying silage and feces for protein and energy determinations. Improved procedures. J. Dairy Sci. 40:173-179.

Duncan, D.B. 1955. Multiple range and multiple F. tests. Biometrics 11:1-42.

Eramus, T., B.L. Penzhorn, and N. Fairall. 1978. Chemical composition of faeces as an index of veld quality. S. Afr. J. Wildl. Res. 8:19-24.

Falvey, L., and A. Woolley. 1974. Losses from cattle faeces during chemical analysis. Aust. J. Exp. Agr. Anim. Husb. 14:716-719.

Fels, H.E., R.J. Moir, and R.C. Rositer. 1959. Herbage intake of grazing sheep in south-western Australia. J. Agr. Res. 10:237.

Forbes, E.B., R.F. Elliot, R.F. Swift, W.H. James, and V.F. Swift. 1946. Variation in determinations of digestive capacity of sheep. J. Anim. Sci. 5:298-305.

Gallup, W.D., and C.S. Hobbs. 1944. The desiccation and analysis of faeces in digestion experiments with steers. J. Anim. Sci. 3:326-332.
Harria, L.E. 1970. Nutrition research techniques for domestic and wild animals. Vol. I. An international record system and procedures for analyzing samples. Utah State Univ. Logan, UT.

Holechek, J.L. 1982. Sample preparation techniques for microhistological analysis. J. Range Manage. 35:267-268.

Holechek, Jerry L, and Raul Valdez. 1985. Magnification and shrub stemmy material influence on fecal analysis accuracy. J. Range Manage. 38:350-352.

Hutchimen, K.J. 1958. Factors governing fecal nitrogen waste in sheep. Aust. J. Agr. Res. 9:508-520.

Putman, R.J. 1985. Facts from faeces. Mammal. Rev. 14:79-97.

Raymond, W.F. 1948. Evaluation of herbage for grazing. Nature. 161-397.

Raymond, W.F., and C.E. Harris. 1954. The laboratory drying of herbage and faeces, and dry matter losses possible during drying. J. Brit. Grassl. Soc. 9:119-130.

Renecker, Lyle A., and Robert J. Hudson. 1985. Estimation of dry matter intake of free-ranging moose. J. Wildl. Manage. 49:785-792.

SAS Institute Inc. 1982. SAS user's guide:statistics, 1982 Ed. Cary, NC:SAS Institute Inc.

Scott, Gretchen, and B.E. Dahl. 1980. Key to selected plant species of Texas using plant fragments. Occasional Papers, The Museum. Texas Tech University.

Sinclair, A.R.E., and C.J. Krebs, and J.N.M. Smith. 1982. Diet quality and food limitation in herbivores: the case of the snowshoe hare. Can. J. Zool. 60:879-897.

Snedecor, G.W., and W.G. Cochran. 1980. Statistical Methods. The Iowa State University Press. Ames, IA.

Sparks, D.R., and J.C. Malechek. 1968. Estimating percentage dry weight in diets using a microscopic technique. J. Range Manage. 21:264-265.

Vavra, M., and J.L. Holechek. 1980. Factors influencing microhistological analysis of herbivore diets. J. Range Manage. 33:371-374.

Williams, O.B. 1969. An improved technique for identification of plant fragments in herbivore feces. J. Range Manage. 22:51-52.

Wofford, Helen, Jerry L. Holechek, M.L. Galzean, Joe D. Wallace, and Manuel Cardenas. 1985. Evaluation of fecal indices to predict cattle diet quality. J. Range Manage. 38:450-454.

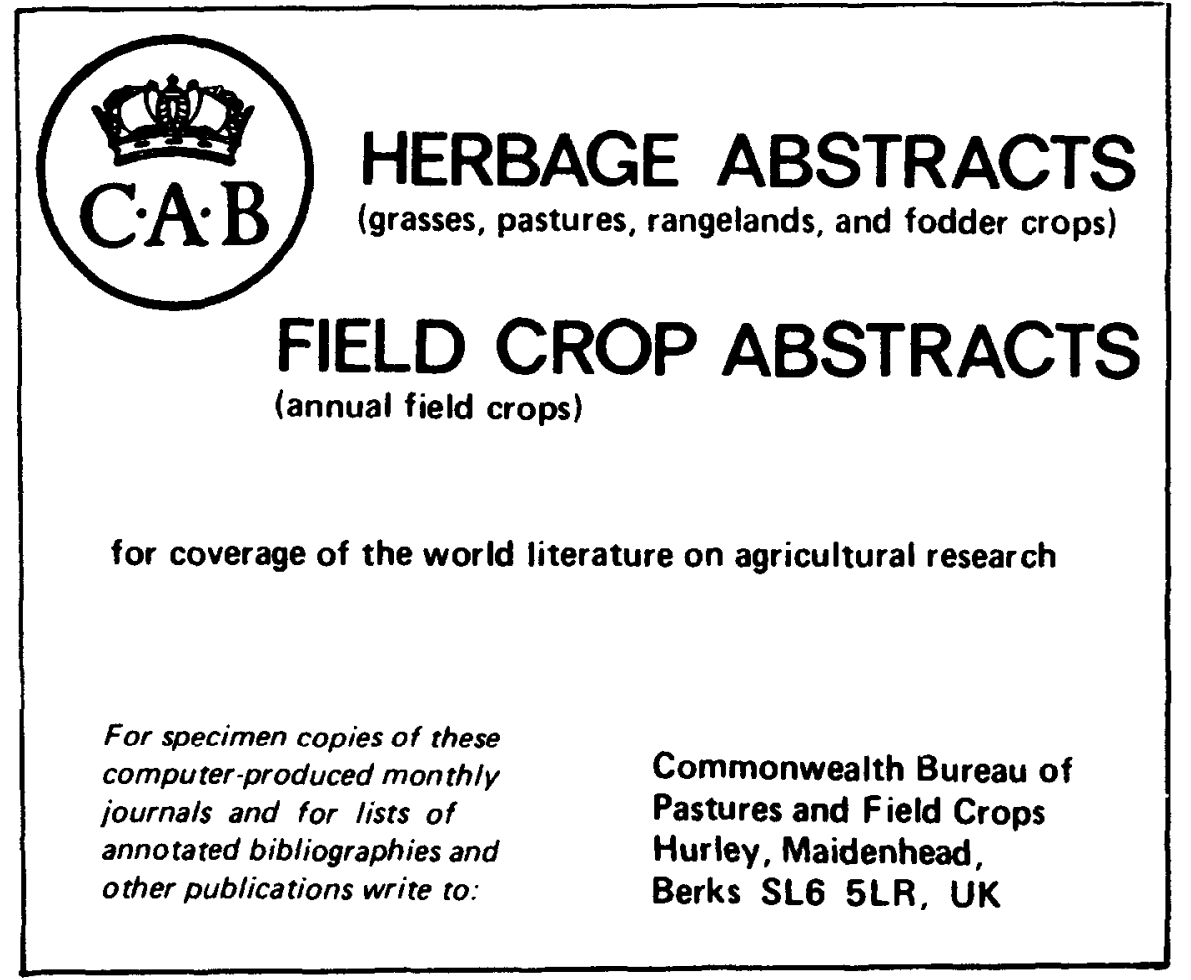

